Original Research

\title{
Ability of Cyanobacteria and Green Algae to Improve Metabolic Activity and Development of Willow Plants
}

\author{
Mieczyslaw Grzesik ${ }^{1}$ Zdzisława Romanowska-Duda ${ }^{2 *}$ \\ ${ }^{1}$ Research Institute of Horticulture, Konstytucji 3 Maja 1/3, 96-100 Skierniewice, Poland \\ ${ }^{2}$ Department of Ecophysiology and Plant Development, University of Lodz, Banacha 12/16, 90-237 Lodz, Poland
}

Received: 7 September 2014

Accepted: 3 December 2014

\begin{abstract}
The ability of Cyanobacteria and green algae to improve physiological activity and plant development gives a promising perspective and has a useful potential in practice, although literature concerning this issue is scanty. The purpose of this study was to assess the influence of two species of Cyanobacteria (Microcystis aeruginosa MKR 0105, Anabaena sp. PCC 7120) and one of green algae (Chlorella sp.) on select physiological processes, determining rooting of cuttings and the subsequent growth of willow (Salix viminalis L.) plants. Two procedures were used to apply sonicated and unsonicated monocultures of Cyanobacteria and green algae to woody cuttings: (i) four-day soaking of cuttings which were then rooted in universal horticulture substrate in a vegetation chamber or in a field and watered with tap water, and (ii) moistening the substrate in which the untreated cuttings were subsequently rooted and plants were grown. The cuttings treated with water, $\mathrm{GA}_{3}$, IBA, Bio-Algeen S90, and environmental sample were the control. The results show that the used monocultures of Cyanobacteria and green algae significantly stimulated some metabolic processes, thus having an important impact on plant development. Their application increased the stability of cytomembranes and intensified activity of net photosynthesis, transpiration, stomatal conductance, dehydrogenases, RNase, acid, and alkaline phosphatase, and decreased intercellular $\mathrm{CO}_{2}$ concentration in the rooted cuttings and plants. These physiological events caused increased rooting of willow cuttings and plant growth under laboratory and field conditions.
\end{abstract}

Keywords: Salix viminalis L., Cyanobacteria, microalgae, metabolic activity, growth

\section{Introduction}

Large-scale Cyanobacteria and green algae production has been studied for decades, due to the wide variety of practical and potentially metabolic products that can be obtained such as food supplements, lipids, enzymes, biomass, polymers, toxins, pigments, tertiary wastewater treatment, and green energy products. Cyanobacteria are one of the major components of the potential source of nitrogen fixation and

*e-mail: romano@biol.uni.lodz.pl convert it into a bioavailable form of ammonium required for plant growth. These organisms have a unique potential to enhance productivity in a variety of agricultural and ecological situations and they play an important role in building up soil fertility, consequently increasing the yield. Biofertilizers, being essential components of organic farming, play a vital role in maintaining long-term soil fertility and sustainability by fixing atmospheric dinitrogen $(\mathrm{N}=\mathrm{N})$, mobilizing fixed macro and micro nutrients, or converting insoluble phosphorus in soil into forms available to plants, thereby increasing their efficiency and availability [1]. 
These microorganisms have been reported to contain nutrients, sugar, and amino acids, and to benefit plants by producing growth-promoting bioregulators (auxin, GA, and cytokinins), vitamins, amino acids, and other secondary metabolites [2-8]. Cyanobacteria strains are able to fix atmospheric nitrogen and enrich the soil, rice, and wheat with this macroelement [9-11]. This blue-green algae can also produce fycocyanine and other active compounds that inhibit the growth of pathogenic bacteria and fungi [12-14], and increase growth and development of gillyflower and grapevine $[15,16]$. Some papers suggest that cyanobacterial activity improves soil structure and porosity by secretion of polysaccharides and mucilage so they can be used as soil biofertilizers [11, 17]. It also has been reported that they can play an important role in symbiosis with other organisms, including higher plants [18]. In recent years, more and more attention has been paid worldwide to the use of Cyanobacteria and green algae to intensify organic plant production, particularly in the context of a changing climate. However, data concerning this issue are still very scarce.

Because of the lack of information, the aim of the presented research was to investigate the influence of Microcystis aeruginosa MKR 0105, Anabaena sp. PCC 7120 (Cyanobacteria), and Chlorella sp. (green algae) monocultures on rooting of cuttings and growth of willow plants under laboratory and field conditions. To elucidate the mechanism of Cyanobacteria and green algae influence on rooting and plant growth, the physiological activity that has an important impact on these processes was studied in a growth room and in the field.

\section{Material and Methods}

Woody cuttings of willow (Salix viminalis L.) were collected from mother plants according to a general procedure and then treated with Cyanobacteria and green algae. Monocultures of two species of Cyanobacteria (Microcystis aeruginosa MKR 0105, Anabaena sp. PCC 7120 , and one green algae Chlorella sp.) were cultivated at the University of Lodz on BG11 medium (ATCC Medium 616) at $27^{\circ} \mathrm{C}$ under an $18 \mathrm{~W}$ FAREL lamp, according to the procedure elaborated by Romanowska-Duda et al. [16]. Prior to application, each monoculture was centrifuged for 2 min. (4000 rev/min.) and suspended in water. Then the number of cells was counted using a Fuchs-Rosenthal hemocytometer. The cell density used in experiments was estimated to be $2.5 \times 10^{5}$ cells $\cdot \mathrm{ml}^{-1}$ of water. For every application, two forms of each monoculture were used, not sonicated and sonicated in the ultrasonic homogenizer (OmniRuptor 4000; Omni International) for 15 minutes, using the titanium head Micro Processing Tip (5/32**) and ultrasound frequency of $20 \mathrm{kHz}$, amplitude $80 \%$, and pulses 0.7 sec., separated by $0.3 \mathrm{sec}$. intervals.

All monocultures of Cyanobacteria and green algae (not sonicated and sonicated), were applied to willow woody cuttings as follows:

1. By soaking of cuttings for 4 days at $20^{\circ} \mathrm{C}$ in these microalgae in flasks, aerated daily (conditioning).
2. One batch of all conditioned cuttings was then planted in a growth room in Phytotoxkit plates (modified by Romanowska-Duda and Grzesik) [19], filled with universal horticulture substrate (mixture of sphagnum peat with quartz sand; $1 / 1, \mathrm{v} / \mathrm{v}$ ) and moistened with distilled water. The conditioned cuttings of the second batch were planted in pots (filled with universal horticulture substrate) and then placed in a field and watered with tap water. The horticulture substrate was mixed with YaraMila Complex fertilizer $\left(0.33 \mathrm{~g} \cdot 1 \cdot\right.$ substrate $\left.^{-1}\right)$ before use in experiments. YaraMila Complex (Yara Poland Sp. z o.o) consisted of: $12 \%$ nitrogen $(5 \%$ nitrate $-7 \%$ ammonium), $11 \%$ phosphorus $\left(\mathrm{P}_{2} \mathrm{O}_{5}\right), 18 \%$ potassium $\left(\mathrm{K}_{2} \mathrm{O}\right)$, magnesium $(2.65 \% \mathrm{MgO})$, sulfur $\left(19.9 \% \mathrm{SO}_{3}\right)$, and trace elements $\mathrm{Zn}(0.02 \%)$ and B $(0.015 \%)$. By continuous moistening of substrate in the Phytotoxkit plates, the unconditioned cuttings were planted and rooted, and then the plants obtained from them were grown.

These experiments were performed in three series. In the growth room, each series was set up in a completely randomized block design, with 30 replicates (Phytotoxkit plates) for each treatment. Every replicate (plate) contained 10 cuttings/plants. The Phytotoxkit plates containing the rooted cuttings and then the growing plants were kept at $20^{\circ} \mathrm{C}$ and $60 \% \mathrm{RH}$, under eight-hour dark/16 hour light cycle - SON-T AGRO $400 \mathrm{~W}, 100 \mu \mathrm{mol} \cdot \mathrm{m}^{-2} \cdot \mathrm{s}^{-1}$. The roots were kept in the dark. In the field, each series was set up in a completely randomized block design, in three replicates for each treatment. Every replicate contained 10 cuttings/plants grown individually in separate three-litre containers.

In all mentioned cases, rooting of cuttings and subsequent growth of plants were studied, as well as their physiological activity to elucidate the mechanism of how these green blue algae affect rooting and plant growth. The effects of Cyanobacteria and green algae application on rooting of cuttings and plant development in the growth room were evaluated by measuring the number of roots and shoots, dynamics of root and shoot growth, and their fresh and dry weight. In the field, total length of shoots (every month) and their fresh and dry weight were examined.

The physiological activity in cuttings and plants (in the growth room and in the field) was studied by measuring the activity of acid $(\mathrm{pH}=6.0)$ and alkaline $(\mathrm{pH}=7.5)$ phosphatase, RNase, dehydrogenase, index of chlorophyll content, activity of net photosynthesis, transpiration, stomatal conductance, intercellular $\mathrm{CO}_{2}$ concentration, and electrolyte leakage from leaves. The cuttings treated similarly with water, $\mathrm{GA}_{3}$ (10-6M), IBA (50 ppm), Bio-Algeen S90 and an environmental sample were the control. A mixture of all algae strains present in water taken from a natural water reservoir constituted an environmental sample.

The number of roots and shoots produced by cuttings, as well as their length, were assessed every two days for one month since the planting of cuttings in the substrate at $20^{\circ} \mathrm{C}$ (growth room) or in field, at temperature depending on weather. Fresh weight of roots and shoots and their dry mass (dried for three days at $130^{\circ} \mathrm{C}$ ) were evaluated at the end of experiments in the growth room or in the field. 
The index of chlorophyll content in the leaves (on the rooted cuttings and plants in the field) was evaluated using a Minolta SPAD-502 chlorophyll meter (Konica Minolta) and expressed in SPAD units. The activity of net photosynthesis, stomatal conductance, intercellular $\mathrm{CO}_{2}$ concentration, and transpiration were measured in the infrared light using a TPS-2 gas analyzer apparatus, PP Systems (USA) $[20,21]$. Activities of acid $(\mathrm{pH}=6)$ and alkaline $(\mathrm{pH}=7.5)$ phosphatase and RNase in the leaves were examined according to the methods described by Knypl and Kabzińska [22]. Total dehydrogenase activities were evaluated by the procedure described by Górnik and Grzesik [23] using SHIMADZU UVmini-1240 spectrophotometer for formazan determination at a wavelength of $480 \mathrm{~nm}$. Electrolyte leakage was measured at $20^{\circ} \mathrm{C} 2$ and 4 hours after placing the leaf segments in test-tubes and adding $3 \mathrm{ml}$ of distilled water using an Elmetron CC-551 microcomputer conductivity meter [23].

The obtained data, given as means from series and repetitions, were processed by applying analysis of variance. The means of chosen parameters were grouped employing Duncan's test at the $\alpha=0.05$ significance level.

\section{Results and Discussion}

The positive effect of Cyanobacteria and green algae on rooting of willow cuttings, plant growth, and their physiological activity were found to be significant. The studies have shown that all 10 treatments applied to cuttings or substrate markedly increased rooting of cuttings and plant growth in comparison to the control variants, in which the cuttings were not treated (Figs. 1, 2, 4, and 5; Table 1). Four-day soaking of cuttings in water caused an intermediate effect. These cuttings rooted and plants grew better than the control, but worse than those subjected to 10 mentioned tested solutions. The most effective proved to be the monocultures of Microcystis aeruginosa MKR 0105, Anabaena sp. PCC 7120 (Cyanobacteria), and Chlorella sp. green

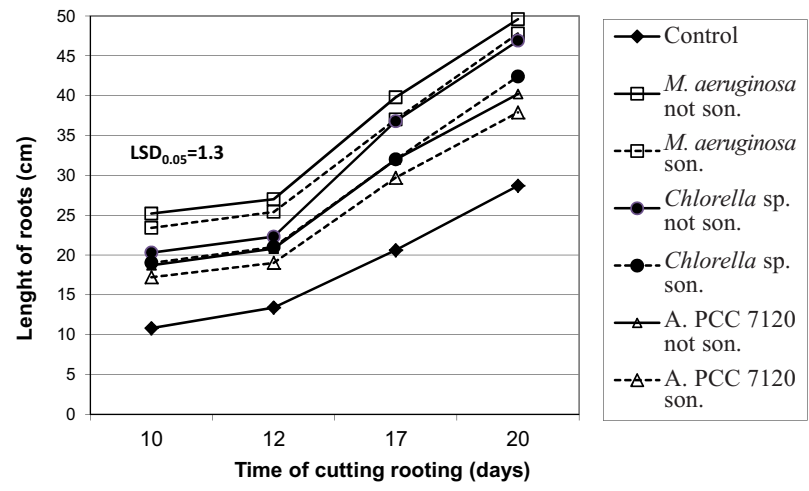

Fig. 1. Dynamics of root growth during rooting of willow cuttings, as affected by the four day application of monocultures of Microcystis aeruginosa MKR 0105, Anabaena sp. PCC 7120 and Chlorella sp. (not sonicated and sonicated) to the conditioned cuttings and subsequent rooting in substrate moistened in water. algae), which applied to cuttings, significantly increased dynamics of their rooting, number and length of formed roots or shoots, and their fresh and dry weight in the growth room and the field, as compared to the treatments with water, $\mathrm{Ga}_{3}$, IBA, Bio-Algeen S90, and the environmental sample. The plants obtained from the cuttings treated with Cyanobacteria and the green algaestrains developed faster and also showed a higher health status. However, the observed improvements depended on the used species of Cyanobacteria and green algae, and methods of application. The obtained results are in line with other experiments indicating stimulatory effects of the tested blue green algae on wheat and their inhibitory influence on growth of pathogenic bacteria and fungi [12-14, 17, 24]. El Modafar et al. [25] found that bioelicitors, which were obtained from the green algae (U. lactuca), had natural defense properties and triggered systemic acquired resistance which seemed to be salicylic acid-dependent and can be used for crop protection. These elicitors significantly reduced wilt development in tomato seedlings caused by Fusarium oxysporum f. sp. Lycopersici. Similar results to those observed in willow showing more beneficial influence of the studied blue green algae than of the standard IBA were also found in cabbage. Hussain and Hasnain [26] observed that the impact of phytohormones of microbial origin, supplemented the medium on regenerate leaf, stem, and root of Brassica oleracea L., was comparable to the standard cytokinins and IAA. However, phytohormones of cyanobacterial origin proved to be better at inducing adventitious roots and shoots on internodal and petiolar segments of Brassica oleracea L. [26].

Glick et al. [27] showed that some plant-interacting bacteria released high levels of IAA. This can cause local changes in the balance of endogenous plant hormones and their nature will depend on the concentration of and sensitivity to these hormones. Sergeeva et al. [28] examined the potential in Cyanobacteria to produce the phytohormone IAA. This was done by screening for endogenous IAA levels and IAA release in a range of free-living cyanobacteria. They observed that Cyanobacteria, and in particular symbiotic isolates, were capable of both accumulating and

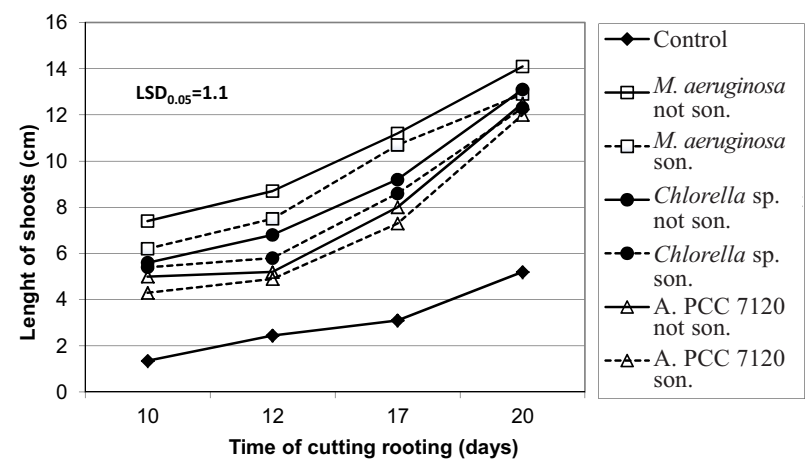

Fig. 2. Dynamics of shoot growth during rooting of willow cuttings, as affected by application of monocultures of Microcystis aeruginosa MKR 0105, Anabaena sp. PCC 7120 and Chlorella sp. (not sonicated and sonicated) to substrate in which the untreated cuttings were rooted and plant grown. 
Table 1. Rooting of willow cuttings and plant growth, as affected by the four-day application of growth stimulators, Cyanobacteria, and green algae to the conditioned woody cuttings or to substrate in which the cuttings were placed and plants were grown.

\begin{tabular}{|c|c|c|c|c|c|c|}
\hline \multirow{2}{*}{$\begin{array}{c}\text { Applied stimulators, } \\
\text { Cyanobacteria or green algae }\end{array}$} & \multicolumn{6}{|c|}{ Parameters of the rooted cuttings and obtained plants } \\
\hline & $\begin{array}{l}\text { Number } \\
\text { of roots }\end{array}$ & $\begin{array}{l}\text { Total length } \\
\text { of roots }[\mathrm{cm}]\end{array}$ & $\begin{array}{c}\text { Fresh weight } \\
\text { of roots [g] }\end{array}$ & $\begin{array}{l}\text { Number } \\
\text { of shoots }\end{array}$ & $\begin{array}{l}\text { Total length } \\
\text { of shoots [cm] }\end{array}$ & $\begin{array}{l}\text { Fresh weight } \\
\text { of shoots [g] }\end{array}$ \\
\hline Control & $10.0 \mathrm{a}$ & $28.7 \mathrm{a}$ & $0.08 \mathrm{a}$ & $1.3 \mathrm{a}$ & $5.2 \mathrm{a}$ & $0.16 \mathrm{a}$ \\
\hline \multicolumn{7}{|c|}{ Four-day application to conditioned cuttings and then their rooting in substrate moistened in water } \\
\hline $\mathrm{H}_{2} \mathrm{O}$ & 12.0 def & $30.1 \mathrm{bcd}$ & $0.11 \mathrm{~b}$ & $2.0 \mathrm{bc}$ & $10.7 \mathrm{c}$ & $0.20 \mathrm{bcd}$ \\
\hline $\mathrm{Ga}_{3} 10^{-6} \mathrm{M}$ & $11.2 \mathrm{abcd}$ & $29.3 \mathrm{abc}$ & $0.11 \mathrm{~b}$ & $2.1 \mathrm{bcd}$ & $10.6 \mathrm{c}$ & $0.20 \mathrm{bcd}$ \\
\hline IBA 50 ppm & $10.9 \mathrm{abcd}$ & $29.0 \mathrm{ab}$ & $0.12 b c$ & $2.0 \mathrm{bc}$ & $8.8 \mathrm{~b}$ & $0.19 \mathrm{bc}$ \\
\hline Bio-Algeen S90 & $12.8 \mathrm{ef}$ & $31.1 \mathrm{de}$ & $0.14 \mathrm{de}$ & $2.2 \mathrm{~cd}$ & $12.0 \mathrm{def}$ & $0.33 \mathrm{f}$ \\
\hline M. aeruginosa Not sonicated & $17.0 \mathrm{j}$ & 49.61 & $0.21 \mathrm{i}$ & $2.8 \mathrm{e}$ & $14.1 \mathrm{~h}$ & $0.47 \mathrm{j}$ \\
\hline M. aeruginosa Sonicated & $15.6 \mathrm{i}$ & $47.8 \mathrm{k}$ & $0.17 \mathrm{~g}$ & $2.2 \mathrm{~cd}$ & $12.9 \mathrm{fg}$ & $0.38 \mathrm{~h}$ \\
\hline Chlorella sp. Not sonicated & $15.3 \mathrm{hi}$ & $46.9 \mathrm{k}$ & $0.20 \mathrm{hi}$ & $2.7 \mathrm{e}$ & $13.1 \mathrm{fg}$ & $0.41 \mathrm{i}$ \\
\hline Chlorella sp. Sonicated & $14.1 \mathrm{gh}$ & $42.4 \mathrm{j}$ & $0.15 \mathrm{ef}$ & $2.6 \mathrm{e}$ & $12.3 \mathrm{efg}$ & $0.36 \mathrm{gh}$ \\
\hline A.PCC 7120 Not sonicated & $13.6 \mathrm{~g}$ & 40.21 & $0.19 \mathrm{~h}$ & $2.6 \mathrm{e}$ & $12,5 \mathrm{efg}$ & $0.42 \mathrm{i}$ \\
\hline A.PCC 7120 Sonicated & $13.1 \mathrm{fg}$ & $35.9 \mathrm{~g}$ & $0.16 \mathrm{fg}$ & $2.6 \mathrm{e}$ & 12.0 def & $0.34 \mathrm{fg}$ \\
\hline Environmental sample & $11.8 \mathrm{cde}$ & $32.2 \mathrm{ef}$ & $0.12 \mathrm{bc}$ & $1.9 \mathrm{~b}$ & $10.6 \mathrm{c}$ & $0.26 \mathrm{e}$ \\
\hline \multicolumn{7}{|c|}{ Application to substrate in which the untreated cuttings were then rooted and plants were grown } \\
\hline $\mathrm{Ga}_{3}$ & $10.4 \mathrm{ab}$ & $29.0 \mathrm{ab}$ & $0.09 \mathrm{a}$ & $1.4 \mathrm{a}$ & $8.9 \mathrm{~b}$ & $0.18 \mathrm{ab}$ \\
\hline IBA & $10.7 \mathrm{abc}$ & $28.9 \mathrm{ab}$ & $0.08 \mathrm{a}$ & $1.4 \mathrm{a}$ & $8.0 \mathrm{~b}$ & $0.18 \mathrm{ab}$ \\
\hline Bio-Algeen & $11.8 \mathrm{cde}$ & $30.5 \mathrm{~cd}$ & $0.11 \mathrm{~b}$ & $2.0 \mathrm{bc}$ & $11.0 \mathrm{~cd}$ & $0.22 \mathrm{~d}$ \\
\hline M. aeruginosa Not sonicated & $15.2 \mathrm{hi}$ & 39.61 & $0.15 \mathrm{ef}$ & $2.3 \mathrm{~d}$ & $13.2 \mathrm{gh}$ & $0.38 \mathrm{~h}$ \\
\hline M. aeruginosa Sonicated & $14.1 \mathrm{gh}$ & $37.2 \mathrm{~h}$ & $0.14 \mathrm{de}$ & $2.0 \mathrm{bc}$ & $12.0 \mathrm{def}$ & $0.37 \mathrm{~h}$ \\
\hline Chlorella sp. Not sonicated & $15.0 \mathrm{hi}$ & $34.6 \mathrm{~g}$ & $0.14 \mathrm{de}$ & $2.1 \mathrm{bd}$ & $12.3 \mathrm{efg}$ & $0.28 \mathrm{e}$ \\
\hline Chlorella sp. Sonicated & $12.0 \mathrm{def}$ & $32.9 \mathrm{f}$ & $0.13 \mathrm{~cd}$ & $2.0 \mathrm{bc}$ & $10,6 \mathrm{c}$ & $0.26 \mathrm{e}$ \\
\hline A.PCC 7120 Not sonicated & $12.2 \mathrm{ef}$ & $32.6 \mathrm{f}$ & $0.13 \mathrm{~cd}$ & $2.1 \mathrm{bd}$ & $12.0 \mathrm{def}$ & $0.22 \mathrm{~d}$ \\
\hline A.PCC 7120 Sonicated & $11.9 \mathrm{cdef}$ & $31.1 \mathrm{de}$ & $0.13 \mathrm{~cd}$ & $2.0 \mathrm{bc}$ & $11,4 \mathrm{cde}$ & $0.21 \mathrm{~cd}$ \\
\hline Environmental sample & $11.8 \mathrm{cde}$ & $30.1 \mathrm{bcd}$ & $0.11 \mathrm{~b}$ & $1.9 \mathrm{~b}$ & $8.8 \mathrm{~b}$ & $0.20 \mathrm{bd}$ \\
\hline $\mathrm{LSD}_{0.05}$ & 1.2 & 1.3 & 0.01 & 0.2 & 1.1 & 0.02 \\
\hline
\end{tabular}

*The data marked with the same letters within a column are not significantly different, according to Duncan multiple range test at an alpha level of 0.05 .

releasing IAA, and suggested that IAA accumulation was stimulated by exogenous tryptophan and might proceed via the indole3-pyruvic acid pathway.

Cyanobacteria may respond to changed phytohormone signals-both those free-living and those in planta. According to Johansson and Bergman [29] Nostoc strains stimulate mitotic activity in host cells close to the site of penetration. They also provoke growth of plant protrusions ramifying through the mucilage-filled cavities infected by Cyanobacteria in bryophytes and Azolla $[30,31]$.

The enhancement of rooting of willow cuttings and plant growth was associated with the increased physiological activity in cells and tissues, which was expressed by greater index of chlorophyll content in the leaves, activity of net photosynthesis, transpiration, and stomatal conductance, but lower intercellular $\mathrm{CO}_{2}$ concentration as well as higher activity of acid $(\mathrm{pH}=6.0)$ and alkaline $(\mathrm{pH}=7.5)$ phosphatase, RNase, and dehydrogenase, and decreased electrolyte leakage from leaves (Tables 2 and 3, Fig. 3). This indicates that the studied Cyanobacteria and green algaestrains contain a potential source of bioactive compounds that activate several metabolic processes, regulating the growth and development of plants. The obtained results are in line with our other studies showing the positive influence of microalgal cell suspensions on cutting rooting, metabolic activity, and plant development of grapes, or on seed germination and seedling growth of sunflower and corn. They also confirm previously 
Table 2. Physiological activity and index of chlorophyll content in willow plant, as effected by the four-day application of growth stimulators, Cyanobacteria and green algaeto the conditioned woody cuttings or to substrate, in which the cuttings were placed and plants were grown.

\begin{tabular}{|c|c|c|c|c|c|}
\hline $\begin{array}{l}\text { Applied stimulators, } \\
\text { Cyanobacteria } \\
\text { or green algae }\end{array}$ & $\begin{array}{l}\text { Net photosynthesis } \\
\left(\mu \mathrm{m} \mathrm{CO}{ }_{2} \cdot \mathrm{m}^{-2} \cdot \mathrm{s}^{-1}\right)\end{array}$ & $\begin{array}{c}\text { Transpiration } \\
\left(\mathrm{mmol} \mathrm{H}_{2} \mathrm{O} \cdot \mathrm{m}^{-2} \cdot \mathrm{s}^{-1}\right)\end{array}$ & $\begin{array}{c}\text { Stomatal } \\
\text { conductance } \\
\left(\mathrm{mmol} \mathrm{H} \mathrm{O}^{-1} \cdot \mathrm{M}^{-2} \cdot \mathrm{s}^{-1}\right)\end{array}$ & $\begin{array}{c}\text { Intercellular } \\
\text { concentrate } \mathrm{CO}_{2} \\
\left(\mu \mathrm{mol} \mathrm{CO} \mathrm{CO}_{2} \text { air } \cdot \mathrm{mol}^{-1}\right)\end{array}$ & $\begin{array}{c}\text { Index of } \\
\text { chlorophyll } \\
\text { content in leaves }\end{array}$ \\
\hline Control & $3.9 \mathrm{a}$ & $1.09 \mathrm{a}$ & $410 \mathrm{a}$ & $303 \mathrm{j}$ & $11.3 \mathrm{a}$ \\
\hline \multicolumn{6}{|c|}{ Four-day application to conditioned cuttings and then their rooting in substrate moistened in water } \\
\hline $\mathrm{H}_{2} \mathrm{O}$ & $4.20 \mathrm{bc}$ & $1.21 \mathrm{~b}$ & $423 \mathrm{bc}$ & $290 \mathrm{gh}$ & $23.3 \mathrm{~b}$ \\
\hline $\mathrm{Ga}_{3} 10^{-6} \mathrm{M}$ & $4.07 \mathrm{ab}$ & $1.10 \mathrm{a}$ & $420 \mathrm{ab}$ & $286 \mathrm{fg}$ & $23.5 \mathrm{~b}$ \\
\hline IBA $50 \mathrm{ppm}$ & $4.03 \mathrm{ab}$ & $1.10 \mathrm{a}$ & $419 \mathrm{ab}$ & $288 \mathrm{gh}$ & $23.4 \mathrm{~b}$ \\
\hline Bio-Algeen S90 & $4.40 \mathrm{cf}$ & $1.21 \mathrm{~b}$ & 434 cde & 278 cde & $33.1 \mathrm{f}$ \\
\hline M. aeruginosa Not sonicated & $4.93 \mathrm{~h}$ & $1.48 \mathrm{f}$ & $469 \mathrm{i}$ & $261 \mathrm{a}$ & $36.8 \mathrm{~h}$ \\
\hline M. aeruginosa Sonicated & $4.63 \mathrm{~g}$ & $1.36 \mathrm{de}$ & $455 \mathrm{gh}$ & $270 \mathrm{~b}$ & $34.8 \mathrm{~g}$ \\
\hline Chlorella sp. Not sonicated & $4.72 \mathrm{~g}$ & $1.37 \mathrm{e}$ & $447 \mathrm{fgh}$ & $269 \mathrm{~b}$ & $34.7 \mathrm{~g}$ \\
\hline Chlorella sp. Sonicated & $4.52 \mathrm{eg}$ & $1.26 \mathrm{bcd}$ & 446 fgh & $271 \mathrm{bc}$ & $32.6 \mathrm{ef}$ \\
\hline A.PCC 7120 Not sonicated & $4.67 \mathrm{~g}$ & $1.30 \mathrm{~b}-\mathrm{e}$ & 442 ef & $271 \mathrm{bc}$ & $34.8 \mathrm{~g}$ \\
\hline A.PCC 7120 Sonicated & $4.56 \mathrm{fg}$ & $1.29 \mathrm{~b}-\mathrm{e}$ & 441 def & $275 \mathrm{bcd}$ & $33.7 \mathrm{fg}$ \\
\hline Environmental sample & 4.33 cde & $1.21 \mathrm{~b}$ & $423 \mathrm{bc}$ & $285 \mathrm{efg}$ & 31.6 cde \\
\hline \multicolumn{6}{|c|}{ Application to substrate in which the untreated cuttings were then rooted and plants were grown } \\
\hline $\mathrm{Ga}_{3}$ & $3.91 \mathrm{a}$ & $1.10 \mathrm{a}$ & $423 \mathrm{bc}$ & $290 \mathrm{gh}$ & $22.5 \mathrm{~b}$ \\
\hline IBA & $3.92 \mathrm{a}$ & $1.10 \mathrm{a}$ & $422 \mathrm{~b}$ & 294 hi & $22.3 \mathrm{~b}$ \\
\hline Bio-Algeen & $4.21 \mathrm{bc}$ & $1.25 \mathrm{bc}$ & $430 \mathrm{bcd}$ & $288 \mathrm{gh}$ & $31.0 \mathrm{c}$ \\
\hline M. aeruginosa Not sonicated & $4.68 \mathrm{~g}$ & $1.36 \mathrm{de}$ & $456 \mathrm{~h}$ & 279 def & $35.0 \mathrm{gh}$ \\
\hline M. aeruginosa Sonicated & 4.37 cef & $1.30 \mathrm{be}$ & 443 ef & $285 \mathrm{efg}$ & $33.1 \mathrm{f}$ \\
\hline Chlorella sp. Not sonicated & 4.42 def & 1.33 cde & 444 efg & $287 \mathrm{gh}$ & $32.5 \mathrm{df}$ \\
\hline Chlorella sp. Sonicated & 4.33 cde & $1.29 \mathrm{~b}-\mathrm{e}$ & $439 \mathrm{def}$ & $287 \mathrm{gh}$ & $31.2 \mathrm{~cd}$ \\
\hline A.PCC 7120 Not sonicated & $4.29 \mathrm{~cd}$ & $1.31 \mathrm{~b}-\mathrm{e}$ & 438 def & $288 \mathrm{gh}$ & $33.0 \mathrm{f}$ \\
\hline A.PCC 7120 Sonicated & $4.29 \mathrm{~cd}$ & $1.28 \mathrm{~b}-\mathrm{e}$ & 434 cde & $289 \mathrm{gh}$ & $32.5 \mathrm{df}$ \\
\hline Environmental sample & $4.20 \mathrm{bc}$ & $1.21 \mathrm{~b}$ & $422 \mathrm{~b}$ & $295 \mathrm{i}$ & $31.0 \mathrm{c}$ \\
\hline $\mathrm{LSD}_{0.05}$ & 0.20 & 0.10 & 11.2 & 7.6 & 1.3 \\
\hline
\end{tabular}

*The data marked with the same letters within column are not significantly different, according to Duncan multiple range test at an alpha level of 0.05 .

described interdependencies between plant growth enhancement and the presence of cyanobacterial strains or methods of their application [7, 32]. Reduced electrolyte leakage from leaves observed in the present experiment indicates that the investigated Cyanobacteria and green algae lowered permeability of cytomembranes. The positive impact of the used strains on cutting rooting and plant growth might have been caused not only by the increased concentration of different bioactive compounds present in green algae and Cyanobacteria [8], but also by their ability to assimilate atmospheric nitrogen and indolic compounds, as it was found in research performed on rice, wheat, gillyflower, grapevine, and Virginia fanpetals [2, 7, $9,15,16,33,34]$.
Increased activity of dehydrogenases shows that the used monocultures include compounds that positively influence the activity of the respiratory cycle in cells. Our research also indicated that substances derived from Cyanobacteria and green algae stimulated the activity of acid and alkaline phosphatase. Phosphatases are a broad group of enzymes that catalyze the hydrolysis of organic phosphorus and are used to assess the potential rate of mineralization of compounds in soil. Moreover, they are responsible for the distribution of phosphorus in a plant. Phosphatases are periplasmic enzymes, i.e. those which are deposited on membrane or between cytoplasmic membranes and a cell wall. Thus their increased activity could also contribute to lowering permeability of membranes, 
Table 3. Activity of the selected enzymes in willow leaves, as effected by the four day application of growth stimulators, Cyanobacteria and green algae to the conditioned woody cuttings or to substrate, in which the cuttings were placed and plants were grown.

\begin{tabular}{|c|c|c|c|c|}
\hline $\begin{array}{c}\text { Applied stimulators, } \\
\text { Cyanobacteria or green algae }\end{array}$ & $\begin{array}{l}\text { Phosphatase }(\mathrm{pH}=6.0) \\
\left(\mathrm{mU} \cdot \mathrm{g}^{-1} \text { f.w. }\right)\end{array}$ & $\begin{array}{l}\text { Phosphatase }(\mathrm{pH}=7.5) \\
\text { (mU. } \mathrm{g}^{-1} \text { f.w.) }\end{array}$ & $\begin{array}{c}\text { RNase } \\
\left(\mathrm{mU} \cdot \mathrm{g}^{-1} \text { f.w. }\right)\end{array}$ & $\begin{array}{l}\text { Total dehydrogenases } \\
\left(\mathrm{mg} \text { formazan } \times \mathrm{g} \cdot \mathrm{leaf}^{1}\right)\end{array}$ \\
\hline Control & $0.56 \mathrm{a}$ & $0.16 \mathrm{a}$ & $2.8 \mathrm{a}$ & $0.79 \mathrm{a}$ \\
\hline \multicolumn{5}{|c|}{ Four day application to conditioned cuttings and then their rooting in substrate moistened in water } \\
\hline $\mathrm{H}_{2} \mathrm{O}$ & $0.66 \mathrm{bcd}$ & $0.21 \mathrm{bc}$ & $3.20 \mathrm{bc}$ & $0.93 \mathrm{~b}$ \\
\hline $\mathrm{Ga}_{3} 10^{-6} \mathrm{M}$ & $0.66 \mathrm{bcd}$ & $0.21 \mathrm{bc}$ & $3.22 \mathrm{bc}$ & $1.10 \mathrm{c}$ \\
\hline IBA 50 ppm & $0.65 \mathrm{bc}$ & $0.21 \mathrm{bc}$ & $3.20 \mathrm{bc}$ & $1.12 \mathrm{c}$ \\
\hline Bio-Algeen S90 & $0.75 \mathrm{e}$ & $0.24 \mathrm{~cd}$ & $3.72 \mathrm{de}$ & $1.13 \mathrm{~cd}$ \\
\hline M. aeruginosa Not sonicated & $0.96 \mathrm{i}$ & $0.36 \mathrm{~g}$ & $4.79 \mathrm{~g}$ & $1.59 \mathrm{~h}$ \\
\hline M. aeruginosa Sonicated & $0.85 \mathrm{gh}$ & $0.28 \mathrm{df}$ & $4.39 \mathrm{f}$ & $1.39 \mathrm{fg}$ \\
\hline Chlorella sp. Not sonicated & $0.85 \mathrm{gh}$ & 0.30 ef & $4.38 \mathrm{f}$ & $1.39 \mathrm{fg}$ \\
\hline Chlorella sp. Sonicated & $0.74 \mathrm{de}$ & 0.29 ef & $3.97 \mathrm{e}$ & $1.27 \mathrm{ef}$ \\
\hline A.PCC 7120 Not sonicated & $0.84 \mathrm{fgh}$ & $0.29 \mathrm{ef}$ & $4.39 \mathrm{f}$ & $1.38 \mathrm{~g}$ \\
\hline A.PCC 7120 Sonicated & 0.76 ef & $0.29 \mathrm{ef}$ & $3.97 \mathrm{e}$ & $1.25 \mathrm{de}$ \\
\hline Environmental sample & $0.66 \mathrm{bcd}$ & $0.24 \mathrm{~cd}$ & $3.22 \mathrm{bc}$ & $1.12 \mathrm{c}$ \\
\hline \multicolumn{5}{|c|}{ Application to substrate in which the untreated cuttings were subsequently rooted and plant were grown } \\
\hline $\mathrm{Ga}_{3}$ & $0.62 \mathrm{abc}$ & $0.19 \mathrm{ab}$ & $3.09 \mathrm{ab}$ & $0.92 \mathrm{~b}$ \\
\hline IBA & $0.61 \mathrm{ab}$ & $0.18 \mathrm{ab}$ & $3.05 \mathrm{ab}$ & $0.93 \mathrm{~b}$ \\
\hline Bio-Algeen & 0.70 cde & $0.20 \mathrm{abc}$ & $3.58 \mathrm{~cd}$ & $1.10 \mathrm{c}$ \\
\hline M. aeruginosa Not sonicated & $0.87 \mathrm{~h}$ & $0.31 \mathrm{f}$ & $4.39 \mathrm{f}$ & $1.46 \mathrm{~g}$ \\
\hline M. aeruginosa Sonicated & 0.78 efg & $0.26 \mathrm{de}$ & $3.98 \mathrm{e}$ & 1.33 ef \\
\hline Chlorella sp. Not sonicated & 0.78 efg & $0.26 \mathrm{de}$ & $3.95 \mathrm{e}$ & 1.32 ef \\
\hline Chlorella sp. Sonicated & 0.76 ef & $0.26 \mathrm{de}$ & $3.81 \mathrm{de}$ & $1.21 \mathrm{cde}$ \\
\hline A.PCC 7120 Not sonicated & 0.78 efg & $0.27 \mathrm{def}$ & $3.94 \mathrm{e}$ & $1.32 \mathrm{ef}$ \\
\hline A.PCC 7120 Sonicated & $0.75 \mathrm{e}$ & $0.26 \mathrm{de}$ & $3.78 \mathrm{de}$ & $1.25 \mathrm{de}$ \\
\hline Environmental sample & $0.66 \mathrm{bcd}$ & $0.21 \mathrm{bc}$ & $3.22 \mathrm{bc}$ & $1.10 \mathrm{c}$ \\
\hline $\mathrm{LSD}_{0.05}$ & 0.08 & 0.04 & 0.39 & 0.12 \\
\hline
\end{tabular}

*The data marked with the same letters within column are not significantly different, according to Duncan multiple range test at an alpha level of 0.05 .

which was observed in these studies. Mohammadi et al. [35] showed that application of biofertilizers had a significant effect on nutrient uptake by wheat after combined application of Cyanobacteria and A. chroococcum. These microalgae caused higher $\mathrm{P}$ content due to their ability to produce organic acid such as gluconic, citric, and fumaric acids under P-limiting conditions. The phosphatases are considered also to be a good indicator of organic phosphorus mineralization potential and biological activity of soil and activity of the second metabolites synthetized by Cyanobacteria and green algae (Table 3) [36-38]. De-Mule et al. [39] and De-Caire et al. [40] revealed significant differences in the dehydrogenase enzyme activities between the material fertilized with algae and the control. This stimulation could be the proof of great benefits of algal cultures that excrete many substances (growth-promoting regula- tors, vitamins, amino acids, polypeptides, antibacterial, and polymers, especially exo-polysaccharides) and that induce growth promotion of plants and increased enzyme activities. Just as in higher plants, downloading phosphate by Cyanobacteria and green algae depends on the $\mathrm{pH}$ of the environment. $\mathrm{pH}$ between 6 and 7 is conducive to the uptake of phosphate ions. Green algae Chlorella sp. use inorganic multi phosphates, and numerous marine algae use phosphate glucose, glycerol and adenosine, guanine and cytosine. In Anabaena sp., acid and alkaline phosphatases able to cleave phosphate residues of polyphosphates with energy release were revealed. It was noted that alkaline phosphatases were synthesized intensively when there was a deficit of phosphorus, and the abundance of phosphorus caused the disappearance of their synthesis or activity. These enzymes are located at the surface of protoplasm. 
Ribonuclease (RNase) present in vegetables constitutes a heterogeneous group of enzymes involved in the process of enzymatic degradation of various fractions of a ribonucleic acid. Activity of these enzymes is increased during seed germination, apoptosis, and aging of plant organs. The results of biochemical analysis published by some authors indicate the stimulation of RNase activity during a phytopathogens attack and under phosphorus deficiency conditions [41-43]. According to Booker [44], modifying the degree of ribonuclease activity of particular genes can be by the specific degradation of mRNA transcripts. Stimulation of the specific RNase activity may play an important role in shaping defense mechanisms in plant tissues.

The performed research showed that the impact of the used algae strains on plant metabolism depended on species of Cyanobacteria and green algae and method of their preparation for the application (sonication or not sonication). Microcystis aeruginosa MKR 0105 was slightly more effective in increasing rooting of cuttings and plant growth than Anabaena sp. PCC 7120 and Chlorella sp. This may depend on the composition of these monocultures, which has not been fully elucidated so far. Moreover, the not sonicated monocultures increased the cutting rooting and plant growth more than the sonicated ones (Figs. 1-5, Tables 1-3). This could be the result of additional assimilation of atmospheric nitrogen by intact cells, which could positively influence not only growth of plants, but also the observed higher content of chlorophyll in leaves [9-11]. Similar interdependence was found in corn [32]. Our studies also showed that applied monocultures of Cyanobacteria and green algae better influenced rooting of cuttings and plant growth than an environmental sample taken from the water reservoir. This indicates that the environmental sample could additionally contain toxic algae species that negatively affect growth of plant and animal cells $[32,45,46]$. For this reason, the use

a)

Application to conditioned cuttings

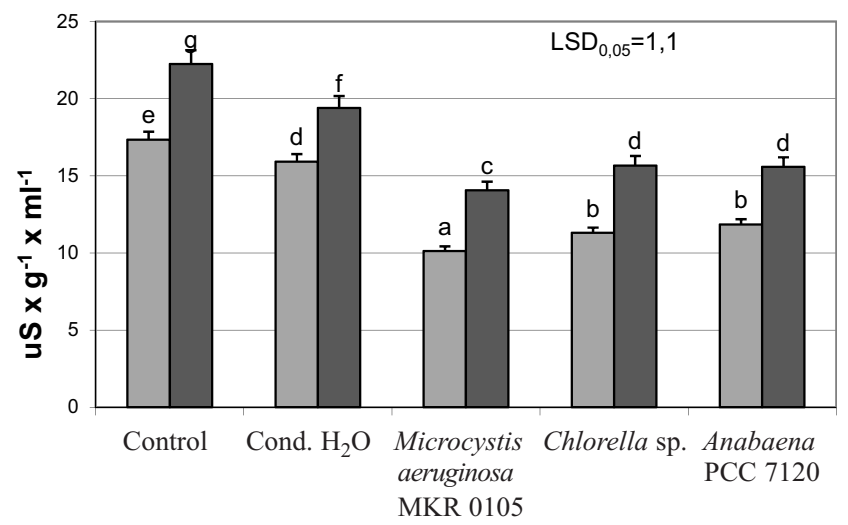

$\square 2 \mathrm{~h} \quad \square 4 \mathrm{~h}$ of the carefully selected monoculture of Cyanobacteria and green algae is more advisable to intensify the development of plants than treatments with unidentified strains.

The effectiveness of used strains, i.e. Microcystis aeruginosa MKR 0105, Anabaena sp. PCC 7120, and Chlorella sp., on cutting rooting and willow plant growth depended also on their application methods. Four-day application of these monocultures to the conditioned cuttings and then their rooting in the substrate moistened with water was significantly more beneficial than their application to the substrate in which the untreated cuttings were then rooted and plants were grown. (Figs. 1, 2, Tables 1-3). This was the result of the earlier imbibition of cuttings and initiation of the metabolic pre-rooting processes before their placement in the substrate. The earlier initiation of physiological processes triggered by the biological compounds (present in the strains) caused immediate rooting of the conditioned cuttings after their planting in the wet substrate, while in the not-conditioned ones the pre-rooting metabolic processes were initiated only after planting, and thus it delayed the rooting. Similar interdependence was found in China aster, tomato, and corn, in which the conditioned and unconditioned seeds were tested $[32,37,38]$.

The obtained results, as well as the presented literature data, indicate that the application of selected forms of Cyanobacteria and green algae can be favorable for growth, development, and metabolic activity of plants. Some of them have the remarkable ability to form intimate symbiotic associations with a wide range of eukaryotic hosts belonging to different plant groups. Cyanobacteria are also biogeochemically important components of diverse ecosystems that play a significant role in carbon and nitrogen cycling. Swarnalakshmi et al. [47] evaluated novel biofilmed preparations using Cyanobacteria (Anabaena torulosa) as a matrix for agriculturally useful bacteria (Azotobacter, Mesorhizobium, Serratia, and Pseudomonas) b)

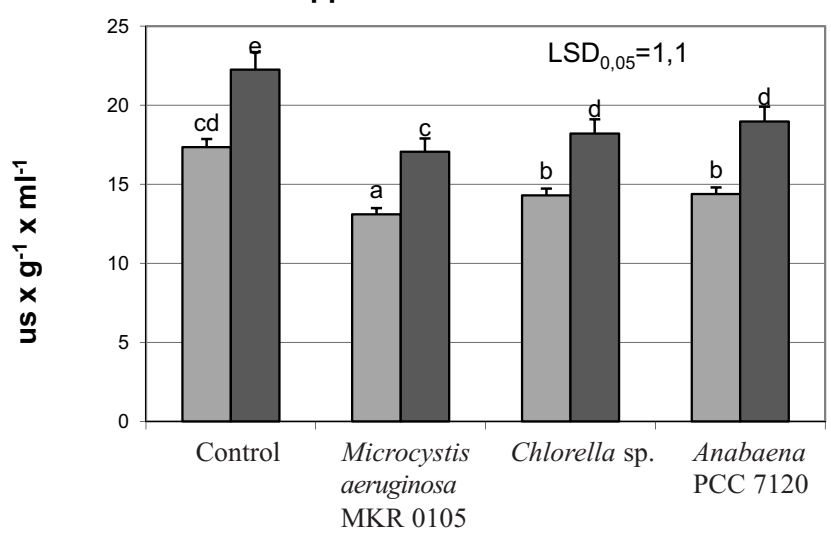

$\square 2 \mathrm{~h} \quad \square 4 \mathrm{~h}$

Fig. 3. Electrolyte leakage from willow leaves placed in water for 2 and 4 hours, as affected by the application of $\mathrm{H}_{2} \mathrm{O}$ or monocultures of Microcystis aeruginosa MKR 0105, Anabaena sp. PCC 7120, and Chlorella sp. to the conditioned cuttings (a) or to substrate (b). The data marked with the same letters (separately for each figure) are not significantly different, according to Duncan multiple range test at an alpha level of 0.05 . 
a)

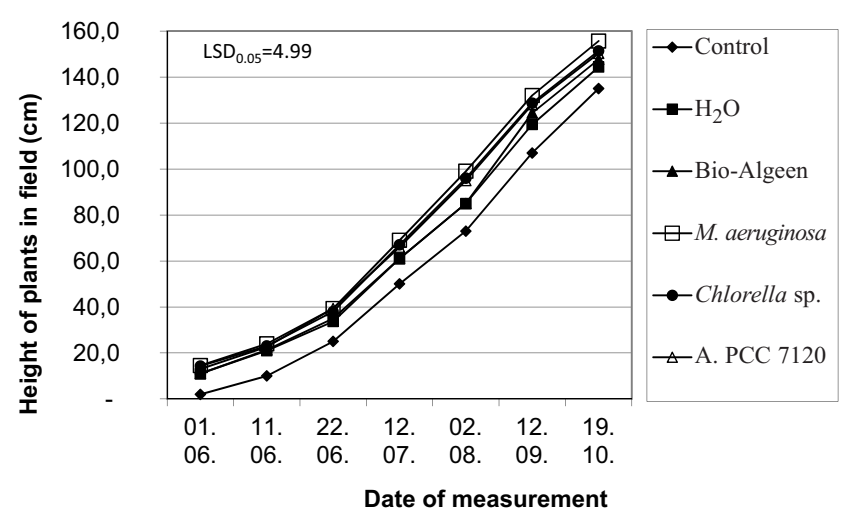

b)

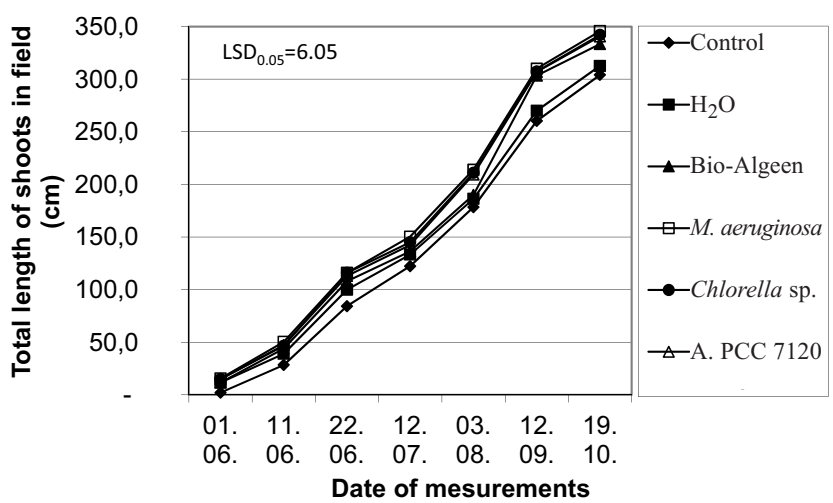

Fig. 4. Height of plants (a) and total length of shoots (b) of willow cultivated in field, as affected by application of not sonicated monocultures of Microcystis aeruginosa MKR 0105, Anabaena sp. PCC 7120, and Chlorella sp. to the conditioned cuttings before placement in substrate.

in wheat crop. The results were promising and showed the correlation between nitrogen fixation and increased $\mathrm{P}$ uptake by plants. Non-toxic cyanobacterial and green algae cultures can be used in ecological and integrated willow cultivation and will facilitate environmental protection by reducing the need to use toxic artificial fertilizers and accelerating plant development. Sahu et al. [1] described that these microorganisms are able to convert complex nutrients into simple nutrients for the availability of the plants and crop yield can be increased by $10-25 \%$ if biofertilizer is used properly. They can also positively affect soil pores and production of adhesive substances. Microorganisms are able to excrete growth-promoting substances such as auxin and gibberellin, vitamins and amino acids. They have the ability to increase water-holding capacity through their jelly structure. Saadatnia and Riahi [48] showed that Cyanobacteria increased soil biomass after their death and decomposition and decreased soil salinity and prevented weed growth.
Additionally, Wilson [49] and Romanowska-Duda et al. [50] noted that after the application of Cyanobacteria as fertilizer the level of phosphorus an nitrogen in soil increased due to decomposition of organic acids. Such increased biomass is capable of absorbing about $20 \%$ more $\mathrm{CO}_{2}$, which is particularly important and useful in mitigating this gas content in the atmosphere. Due to the limited amount of literature data and the increasing worldwide interest in this issue, further studies are required to elucidate this phenomenon, as well as to identify active compounds released by Cyanobacteria and green algae strains.

\section{Conclusions}

1. The application of various forms of Cyanobacteria and green algae (Microcystis aeruginosa MKR 0105, Anabaena sp. PCC 7120 and Chlorella sp.) significant-

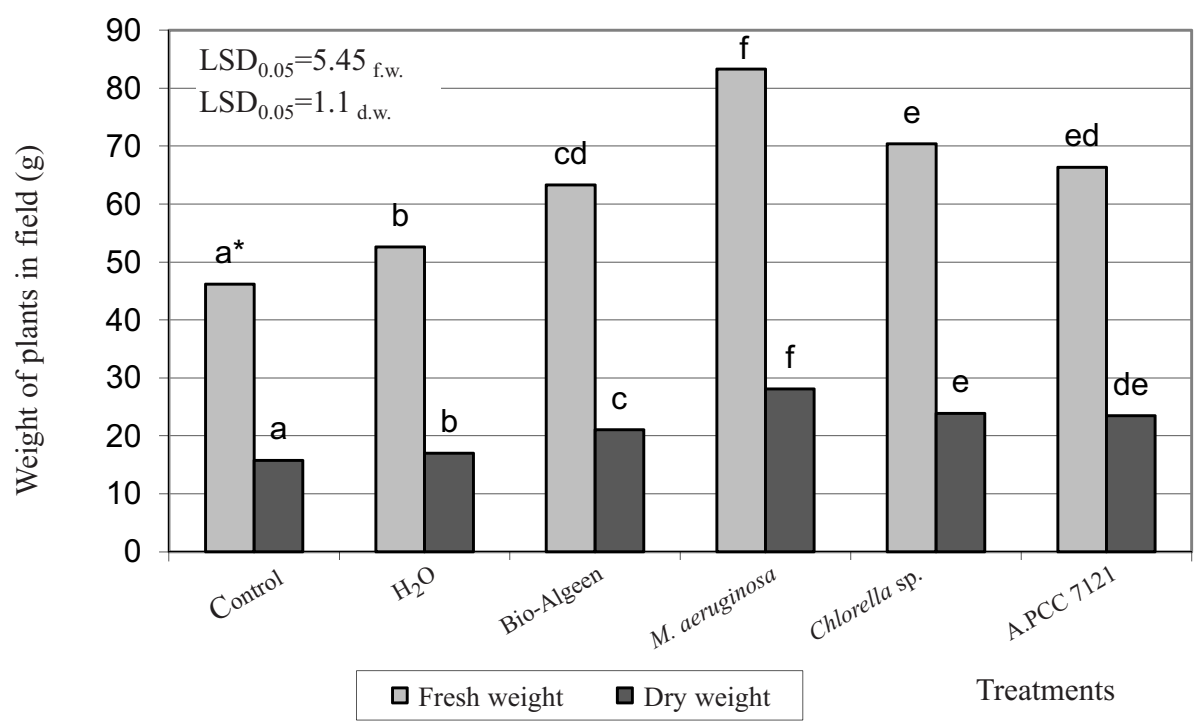

Fig. 5. Fresh and dry weight of willow plants in October, as affected by the application of unsonicated monocultures of Microcystis aeruginosa MKR 0105, Anabaena sp. PCC 7120, and Chlorella sp. to the conditioned cuttings before placement in substrate. The data marked with the same letters are not significantly different, according to Duncan multiple range test at an alpha level of 0.05 . 
ly increase rooting of willow cuttings, plant growth, and stability of cytomembranes, and intensifies activity of net photosynthesis, transpiration, stomatal conductance, RNase, acid, alkaline phosphatase, and dehydrogenase, and decreases intercellular $\mathrm{CO}_{2}$ concentration.

2. Four-day application of Cyanobacteria and green algae strains to the conditioned cuttings and then their rooting in the substrate moistened with water were significantly more effective than their application to the substrate in which the untreated cuttings were then rooted and plants were grown.

3. The use of biofertilizers such as non-toxic Cyanobacteria and green algae is economic, environmentally friendly, and increases crop productivity of willow.

4. Many questions have to be addressed to elucidate the specificity of symbiosis and the criteria for being symbiotically competent concerning both Cyanobacteria and a host, and as well as the factors affecting this event.

5. Cyanobacteria are able to increase crop yield by making the soil fertile and help to create an environmentally friendly agro-ecosystem that ensures economic viability. Cyanobacterial fertilizers also contribute to stabilization of soil and organic matter, release growth promoting substances, improve the physico-chemical properties of soil, and solubilize phosphates.

6. This is the new biological method considered one of the most promising alternative strategies for crop and soil protection.

\section{Acknowledgements}

This work was supported by the National Science Center in Poland under Grant No. N N304 102940.

\section{References}

1. SAHU D., PRIYADARSHANI I., RATH B. Cyanobacteria - as potential biofertilizer. CIB Tech Journal of Microbiology ISSN: 2319-3867. 1, (2-3), 20, 2012.

2. HAROUN S.A., HUSSEIN M.H. The promotive effect of algal biofertilizers on growth, protein pattern and some metabolic activities of Lupinus termis plants grown in siliceous soil. Asian Journal of Plant Sciences. 2, (13), 944, 2003.

3. MASOJÍDEK J., PRÁŠIL O. The development of microalgal biotechnology in the Czech Republic. J. Ind. Microbiol. Biot. 37, (12), 1307, 2010.

4. CHOJNACKA A., ROMANOWSKA-DUDA Z.B., GRZESIK M., PSZCZOLKOWSKI W., SAKOWICZ T. Cyanobacteria as a source of bioactive compounds for crop cultivation. In: K. Wolowski, J. Kwandrans, A.Z. Wojtal (Eds), Taxonomy the queen of science - the beauty of algae. Book of abstracts of the $29^{\text {th }}$ International Phycological Conference Krakow. pp. 81-82, 2010.

5. NUNNERY J.K., MEVERS E., GERWICK W.H. Biologically active secondary metabolites from marine cyanobacteria. Curr. Opin. Biotech. 21, (6), 787, 2010.

6. PEREZ-GARCIA O., ESCALANTE F.M.E., DE-BASHAN L.E., BASHAN Y. Heterotrophic cultures of microalgae: Metabolism and potential products. Water Res. 45, 11, 2011.
7. PSZCZOLKOWSKI W., ROMANOWSKA-DUDA Z., OWCZARCZYK A., GRZESIK M., SAKOWICZ T., CHOJNACKA A. Influence of secondary metabolites from Cyanobacteria on the growth and plant development. Phycological Reports: Current advances in algal taxonomy and its applications: phylogenetic, ecological and applied perspective. Institute of Botany Polish, Academy of Sciences, Krakow. pp. 195-203, 2012

8. MARKOU G., NERANTZIS E. Microalgae for high-value compounds and biofuels production: A review with focus on cultivation under stress conditions. Biotechnol. Adv. 31, 1532, 2013.

9. SPILLER H., GUNASEKARAN M. Ammonia-excreting mutant strain of the cyanobacterium Anabaena variabilis supports growth of wheat. Applied of Microbiology and Biotechnology. 33, (4), 477, 1990.

10. NILSSON M., RASMUSSEN U., BERGMAN B. Competition among symbiotic cyanobacterial Nostoc strains forming artificial associations with rice (Oryza sativa). FEMS Microbiology Letters. 245, 139, 2005.

11. KARTHIKEYANB N., PRASANNAA R., NAINB L., KAUSHIK B.D. Evaluating the potential of plant growth promoting cyanobacteria as inoculants for wheat. Eur. J. Soil Biol. 43, (1), 23, 2007.

12. FALCH B.S., KONIG G.M., WRIGHT A.D., STICHER O., ANGERHOFER C.K., PEZZUTO J.M., BACHMANN H. Biological activities of Cyanobacteria: evaluation of extracts and pure compounds. Planta Medica. 61, 321, 1995.

13. KREITLOW S., MUNDT S., LINDEQUIST U. Cyanobacteria - a potential source of new biologically active substances. J. Biotechnol. 70, 61, 1999.

14. BURJA A.M., BANAIGS B., ABOU-MANSOUR E., BURGESS J.G., WRIGHT P.C. Marine cyanobacteria - a prolific source of natural products. Tetrahedron. 57, 9347, 2001.

15. SHANAN N.T., HIGAZY A.M. Integrated biofertilization management and cyanobacteria application to improve growth and flower quality of Matthiola incana. Research Journal of Agriculture and Biological Science. 5, (6), 1162, 2009.

16. ROMANOWSKA-DUDA Z.B., GRZESIK M., OWCZARCZYK A., MAZUR-MARZEC H. Impact of intra and extracellular substances from Cyanobacteria on the growth and physiological parameters of grapevine (Vitis vinifera). In: $20^{\text {th }}$ International Conference on Plant Growth Substance (IPGSA), Book of abstracts 28.0702.08.2010. Universitat Rovira i Virgili, Tarragona. Spain, $118,2010$.

17. NAIN L., RANA A., JOSHI M., JADHAV S.D., KUMAR D., SHIVAY Y.S., PAUL S., PRASANNA R. Evaluation of synergistic effects of bacterial and cyanobacterial strains as biofertilizers for wheat. Plant Soil. 331, 217, 2010.

18. GORELOVA O.A. Communication of cyanobacteria with plant partners during association formation. Microbiology. 75, (4), 465, 2006.

19. ROMANOWSKA-DUDA Z.B., GRZESIK M. The use of biometric measurements of plants in the environment mionitoring and biomass production for renewal energy. In: Kolwzan B, Grabasa K. (Eds.). Ekotoksykologia w Ochronie Środowiska, PZITS. pp. 327-334, 2008 [In Polish].

20. KALAJI M.H., CARPENTIER R., ALLAKHVERDIEV S.I., BOSA K. Fluorescence parameters as an early indicator of light stress in barley. Journal Photochemistry and Photobiology B. 112, 1, 2012. 
21. KALAJI M.H., SCHANSKER G., LADLE R.J., GOLTSEV V., BOSA K., ALLAKHVERDIEV S. I., BRESTIC M., BUSSOTTI F., CALATAYUD A., DĄBROWSKI P., ELSHEERY N. I, FERRONI L., GUIDI L., HOGEWONING S. W., JAJOO A., MISRA A. N., NEBAUER S. G., PANCALDI S., PENELLA C., POLI D., POLLASTRINI M., ROMANOWSKA-DUDA Z. B., RUTKOWSKA B., SERÔDIO J., SURESH K., SZULC W., TAMBUSSI E., YANNICCARI M., ZIVCAK M. Frequently Asked Questions about chlorophyll fluorescence: practical issues. Photosynth. Res. (DOI 10.1007/s11120-014-0024-6), 2014.

22. KNYPL J.S., KABZIŃSKA E. Growth, phosphatase and ribonuclease activity in phosphate deficient Spirodela oligorrhiza cultures. Biochem. Physiol. Pflanzen. 17, 279, 1977.

23. GORNIK K., GRZESIK M.. Effect of Asahi SL on China aster 'Aleksandra' seed yield, germination and some metabolic events. Acta Physiol. Plant. 24, (4), 379, 2002.

24. RANA A., JOSHI M., PRASANNA R., SHIVAY R.S., NAIN L. Biofortification of wheat through inoculation of plant growth promoting rhizobacteria and cyanobacteria. Eur. J. Soil Biol. 50, 118, 2012.

25. EL MODAFAR C., ELGADDA M., EL BOUTACHFAITIB R., ABOURAICHA E., ZEHHARA N., PETIT E., EL ALAOUI-TALIBIA Z., COURTOISB B., COURTOISB J. Induction of natural defence accompanied by salicylic aciddependant systemic acquired resistance in tomato seedlings in response to bioelicitors isolated from green algae. Sci. Hortic. - Amsterdam. 138, 55, 2012.

26. HUSSAIN A., HASNAIN S. Comparative assessment of the efficacy of bacterial and cyanobacterial phytohormones in plant tissue culture. World Journal Microbiology and Biotechnology. 28, 1459, 2012.

27. GLICK B.R., PATTEN C.L., HOLGUIM G., PENROSE D.M. Biochemical and genetic mechanisms used by plant growth promoting bacteria. ICP, Covent Garden, London. 1999.

28. SERGEEVA E., LIAIMER A., BERGMAN B. Evidence for production of the phytohormone indole-3-acetic acid by cyanobacteria. Planta. 215, 229, 2002.

29. JOHANSSON C., BERGMAN B. Early events during the establishment of Gunnera-Nostoc symbiosis. Planta. 188, 403, 1992.

30. RODGERS G.A., STEWART W.D.P. The cyanophytehepatic symbiosis. Morphology and physiology. New Phytol. 78, 441, 1977.

31. PETERS G.A. Azolla and other plant-cyanobacteria symbioses: aspects of form and function. Plant Soil. 137, 193, 1991.

32. GRZESIK M., ROMANOWSKA-DUDA Z.B. Improvements in Germination, Growth, and Metabolic Activity of Corn Seedlings by Grain Conditioning and Root Application with Cyanobacteria and Microalgae. Pol. J. Environ. Stud. 23, (4), 1147, 2014.

33. OBREHT Z., KERBY N.W., GANTAR M., ROWELL P. Effects of root-associated $\mathrm{N}_{2}$-fixing cyanobacteria on the growth and nitrogen content of wheat (Triticum vulgare $\mathrm{L}$.) seedlings. Biol. Fert. Soils. 15, (1), 68, 1993.

34. GRZESIK M., ROMANOWSKA-DUDA Z.B. The effect of potential climatic changes, Cyanobacteria, Biojodis and Asahi SL on development of the Virginia fanpetals (Sida hermaphrodita) plants. Pamiętnik Pulawski. 151, 483, 2009.

35. MOHAMMADI K., GHALAVAND A., AGHAALIKHANI M. Study the Efficacies of Green Manure Application as Chickpea Per Plant. World Academy of Science, Engineering and Technology 46, 233, 2010.
36. DICK W.A., TABATABAI M.A. Significance and potential uses of soil enzymes. In: FB Metting (Ed). Soil microbial ecology: application in agricultural and environmental management. Dekker, New York. pp. 95-125, 1993.

37. BADEK B., VAN DUIJN B., GRZESIK M. Effects of water supply methods and seed moisture content on germination of China aster (Callistephus chinensis) and tomato (Lycopersicon esculentum Mill.) seeds. Eur. J. Agron. 24, (1), 45, 2006.

38. BADEK B., VAN DUIJN B., GRZESIK M. Effects of water supply methods and incubation on germination of China aster (Callistephus chinensis) seeds. Seed Sci. Technol. 35, (3), 569, 2007.

39. DE-MULE M.C.Z., DE CAIRE G.Z., DE CANO M.S., PALMA R.M., COLOMBO K. Effect of cyanobacterial inoculation and fertilizers on rice seedlings and post harvest soil structure. Comm. Soil Sci.Plant Anal. 30, 97, 1999.

40. DE-CAIRE G.Z., DE CANO M.S., PALMA R.M., DE MULE C.Z. Changes in soi enzymes activity by cyanobacterial biomass and exo-polysaccharides. Soil Biol. Biochem. 32, 1985, 2000.

41. LEHMANN K., HAUSE B., ALTMANN D., KÖCK M. Tomato ribonuclease LX with the functional endoplasmic reticulum retention motif $\mathrm{HDEF}$ is expressed during programmed cell death processes, including xylem differentiation, germination, and senescence. Plant Physiol. 127, 436, 2001.

42. SINDELAROVA M., SINDELAR L., WILHELMOVA N., PROCHAZKOVA D. Changes in key enzymes of viralRNA biosynthesis in chloroplasts from PVY and TMV infected tobacco plants. Biol. Plant. 49, (3), 471, 2005.

43. SRIVASTAVA S., EMERY R.J.N., KUREPIN L.V., REID D.M., FRISTENSKY B., KAV N.N.V. Pea PR 10.1 is a ribonuclease and its transgenic expression elevates cytokinin levels. Plant Growth Regul. 49, (1), 17, 2006.

44. BOOKER F.L. Influence of ozone on ribonuclease activity in wheat (Triticum aestivum) leaves. Physiol. Plant. 120, (2), 249, 2004.

45. ROMANOWSKA-DUDA Z., TARCZYŃSKA M. The influence of Microcystin-LR and hepatotoxic cyanobacterial extract on water plant (Spirodela oligorrhiza). Environmental. Toxicology, by John Wiley \& Sons, Inc. 17, (3), 434, 2002.

46. ROMANOWSKA-DUDA Z., MANKIEWICZ J., TARCZYŃSKA M.,. WALTER Z., ZALEWSKI M. The effect of toxic cyanobacteria (blue-green algae) on water plants and animal cells. Pol. J. Environ. Stud. 11, (5), 561, 2002.

47. SWARNALAKSHMI K., PRASANNA C.R., KUMAR A., PATTNAIK S.C., CHAKRAVARTY K.C., SHIV Y.S.A., SINGH B.R., SAXENA A.K. Evaluating the influence of novel cyanobacterial biofilmed biofertilizers on soil fertility and plant nutrition in wheat. Eur. J. Soil Biol. 55, 107, 2013.

48. SAADATNIA H., RIAHI H. Cyanobacteria from paddy fields in Iran as a biofertilizer in rice plants. Plant Soil and Environment 55, (5), 207, 2009.

49. WILSON L.T. Cyanobacteria: A Potential Nitrogen Source in Rice Fields. Texas Rice 6, 9, 2006.

50. ROMANOWSKA-DUDA Z., WOLSKA A., MAŁECKA A. Influence of blue-green algae as nitrogen fertilizer supplier in regulation of water status in grapevines under stress conditions. COST 858: Water Transport and Aquaporins in Grapevines, October 20-23, Alcudia, Spain. 7, 2004. 